\title{
Practolol therapy associated with a systemic lupus erythematosus-like syndrome and an inhibitor to factor XIII
}

\author{
GILLIAN R. MILNER ${ }^{1}$, P. J. L. HOLT, JILL BOTTOMLEY, AND \\ J. E. MACIVER
}

From the Haematology Department, Clinical Laboratories and Rheumatism Research Centre, Manchester Royal Infirmary

SUMmARY A patient is described who had an inhibitor to coagulation factor XIII associated with serum autoantibodies to certain tissues. The relationship of these abnormal findings to practolol therapy suggests that this was practolol-induced lupus erythematosus. Further investigations delineating the site of action of the inhibitor to factor XIII are reported.

Since its introduction into the United Kingdom in 1970, practolol, a cardioselective beta-adrenoceptor antagonist, has been widely used for the treatment of angina pectoris, cardiac dysrhythmias, and, to a lesser extent, hypertension. However, a number of serious complications associated with the use of practolol have become apparent. In 1973 a druginduced lupus erythematosus (SLE) syndrome was described (Raftery and Denman, 1973) and, more recently, an oculomucocutaneous syndrome (Wright, 1975) and sclerosing peritonitis (Brown et al., 1974) have been reported.

We here describe a patient, who, while receiving practolol, developed a bleeding diathesis, and some of the features of drug-induced SLE. These clinical findings were associated with a variety of autoantibodies, and an inhibitor of coagulation factor XIII. The association of drug-induced SLE and an inhibitor to this factor has not previously been reported.

\section{Case report}

A 70-year-old man gradually developed a tense haematoma in the left lower leg and a small effusion into the knee together with bruising of the right forearm. There was no history of trauma or previous personal or familial bleeding tendency. He had had

'Present address: Department of Paediatrics, Children's Hospital, Sheffield S10 2TH

Received for publication 9 February 1977 angina pectoris for several years and had been taking trinitrin and practolol at a dose of $100 \mathrm{mg}$ twice daily for two and a half years. Shortly after starting practolol therapy he developed a transient, nonirritant, maculopapular rash, mainly on the trunk. His only other therapy was Gaviscon for symptoms due to a hiatus hernia.

He had no skin rash, Schirmer's test was positive in the left but not in the right eye, and there were no other ocular changes. Shoulder joints showed some restriction of terminal movement due to pain but no swelling. There were no other abnormal physical findings.

The haemoglobin was $8.3 \mathrm{~g} / \mathrm{dl}$ and the white cell count was $11 \times 10^{9} / 1$ with a normal differential count. The following tests were within normal limits: urea and electrolytes, liver function, plasma protein electrophoresis, immunoglobulins, platelet count, bleeding time, and euglobin clot lysis time. The ESR was $42 \mathrm{~mm}$ per hour (Westergren). Plasma fibrinogen was $605 \mathrm{mg} / 100 \mathrm{ml}(6.5 \mathrm{~g} / \mathrm{l})$ and fibrin degradation products were present to a titre of 1 in 8 (normal $<1$ in 4).

Fibrin ligation was impaired; clots were prepared by recalcifying the patient's plasma with $25 \mathrm{mM}$ $\mathrm{CaCl}_{2}$ and these dissolved in less than five minutes in both $1 \%$ monochloracetic acid (MCA) and $5 \mathrm{M}$ urea. Clots produced from normal plasma remained insoluble in both reagents for 24 hours. A clot formed from 1:1 mixture of normal and patient's plasma dissolved within four minutes in solutions of both MCA and urea. The presence of an inhibitor against factor XIII was thus demonstrated. 
Antinuclear factor (ANF) was strongly positive ( $>1: 40$ ). DNA antibodies were 31 units (normal $<25$ units, kindly measured by the Clinical Research Division, Kennedy Institute of Rheumatology). An occasional LE cell was seen on one out of three occasions. Complement studies were normal apart from a marginal lowering of haemolytic complement to 38.5 units $/ \mathrm{ml}$ (normal $45-180$ units $/ \mathrm{ml}$ ). Tissue autoantibodies were present to striated muscle and reticulin but not to smooth muscle or mitochondria. The FII latex agglutination test was strongly positive $(>1: 640)$ but the Rose-Waaler test was negative $(<1: 8)$. Radiographs of both shoulders showed osteroporotic changes only.

Gradual conversion from practolol to propranolol therapy was carried out uneventfully. The haematoma in the leg and the knee effusion slowly resolved over the next three weeks. There was only one minor episode of bruising in the ensuing weeks although the factor XIII inhibitor persisted. Six weeks after the onset of bleeding, prednisone, $30 \mathrm{mg}$ daily, was started but was tailed off within six weeks because of a recurrence of epigastric pain. A barium meal at this time showed superficial mucosal ulceration of a hiatus hernia. Sixteen weeks after practolol treatment was terminated the inhibitor showed diminished activity and other serological findings gradually returned to normal (Table). DNA antibodies fell to 18 units $/ \mathrm{ml}$ and eventually to 0 units/ml.

STUDIES ON THE FACTOR XIII INHIBITOR The inhibitor was present in both serum and plasma, was non-dialysable, and was destroyed by heating at $70^{\circ} \mathrm{C}$ for five minutes. Incubation of plasma with cysteine ( $0.1 \mathrm{M}$ for 18 hours) had no effect on increasing clot stability.

A sample of the patient's plasma $(5 \mathrm{ml})$ was applied to a column $(45 \times 2.5 \mathrm{~cm})$ containing Biogel A5m (5\% agarose gel) and eluted with tris/citrate/saline buffer $(0.15 \mathrm{M} \mathrm{NaCl}, 0.05 \mathrm{M}$ Tris hydroxymethyl amino methane, $0.005 \mathrm{M}$ tri-sodium citrate; $\mathrm{pH}$ ad- justed to $7 \cdot 4$ with $\mathrm{HCI}$ ). The elution pattern obtained is illustrated in the Figure. Peak I of the eluate contained fibrinogen and, when treated with thrombin ( 2 units $/ \mathrm{ml}$ ) in the presence of $4 \mathrm{mM} \mathrm{CaCl}$, gave a clot which was insoluble in $1 \% \mathrm{MCA}$ or $5 \mathrm{M}$ urea. This indicated the presence of factor XIII in the patient's plasma.

Factor XIII inhibitor activity was found to be associated with fractions which eluted with the same volume of buffer as did the major protein component in a sample of bovine $\gamma$-globulin applied to the same column (hatched area on Figure). The eluate containing the inhibitor was concentrated by ultrafiltration (amicon Diaflo UM 10 membrane). The concentrate was found to inhibit factor XIII ${ }^{a}-$ catalysed incorporation of the fluorescent amine, monodansyl cadaverine and ${ }^{14} \mathrm{C}$ labelled putrescine (Radiochemical Centre, Amersham) into casein (Lorand and Gotoh, 1970). The inhibitor was equally effective against factor XIII activated by thrombin in situ or preactivated factor XIII ${ }^{a}$ (prepared by passing purified factor XIII down a column containing thrombin covalently bound to $\mathrm{CNBr}$ activated agarose gel (Walton and Luck, 1976)). The inhibitory effect was not imparied by incubation of the inhibitor, activated factor XIII $\left(\mathrm{XIII}^{\mathrm{a}}\right)$, casein, and ${ }^{14} \mathrm{C}$-putrescine together in the presence of practolol $(10 \mathrm{mM})$ and desacetylpractolol (10 mM).

\section{Discussion}

Factor XIII inhibitors have been reported in congenital factor XIII deficiency (Lorand et al., 1969). Our patient, however, had no personal or family history of a bleeding diathesis and was shown to have normal factor XIII activity, both during and after the acute haemorrhagic episode. Inactive factor XIII, capable of reactivation by cysteine, has been described in hepatic disease (Nussbaum and Morse, 1964). He had no evidence of hepatic dysfunction, and incubation of his plasma with cysteine

Table Relationship of serum autoantibodies and factor XIII inhibitor

\begin{tabular}{|c|c|c|c|}
\hline \multirow[t]{2}{*}{ Investigation } & \multicolumn{3}{|l|}{ Relation to therapy } \\
\hline & $\begin{array}{l}\text { Practolol } 200 \mathrm{mg} \text { daily, no } \\
\text { prednisone }\end{array}$ & $\begin{array}{l}16 \text { weeks after practolol, } 6 \text { weeks } \\
\text { after prednisone }\end{array}$ & $\begin{array}{l}33 \text { weeks after practolol, } 23 \text { weeks } \\
\text { after prednisone }\end{array}$ \\
\hline $\begin{array}{l}\text { Antinuclear factor } \\
\text { Antibodies to striated muscle } \\
\text { Antibodies to reticulin } \\
\text { Latex agglutination } \\
\text { Clot lysis* time in } 1 \% \mathrm{MCA} \\
\text { Clot lysis** time in } 5 \mathrm{M} \text { urea }\end{array}$ & $\begin{array}{l}+++ \\
+(1: 10) \\
+ \\
\text { Pos } \geqslant 1 / 640 \\
4 \text { min } \\
5 \text { min }\end{array}$ & $\begin{array}{l}+ \\
\text { Not done } \\
+ \\
+ \\
\text { Neg }<40 \\
9.5 \mathrm{~min} \\
5.5 \mathrm{~h}\end{array}$ & $\begin{array}{l}\text { Neg } \\
\text { Neg } \\
\text { Neg } \\
\text { Neg }<40 \\
>1 \mathrm{~h} \\
>24 \mathrm{~h}\end{array}$ \\
\hline
\end{tabular}

* normal time $>1 \mathrm{~h}$.

**normal time $>24 \mathrm{~h}$. 


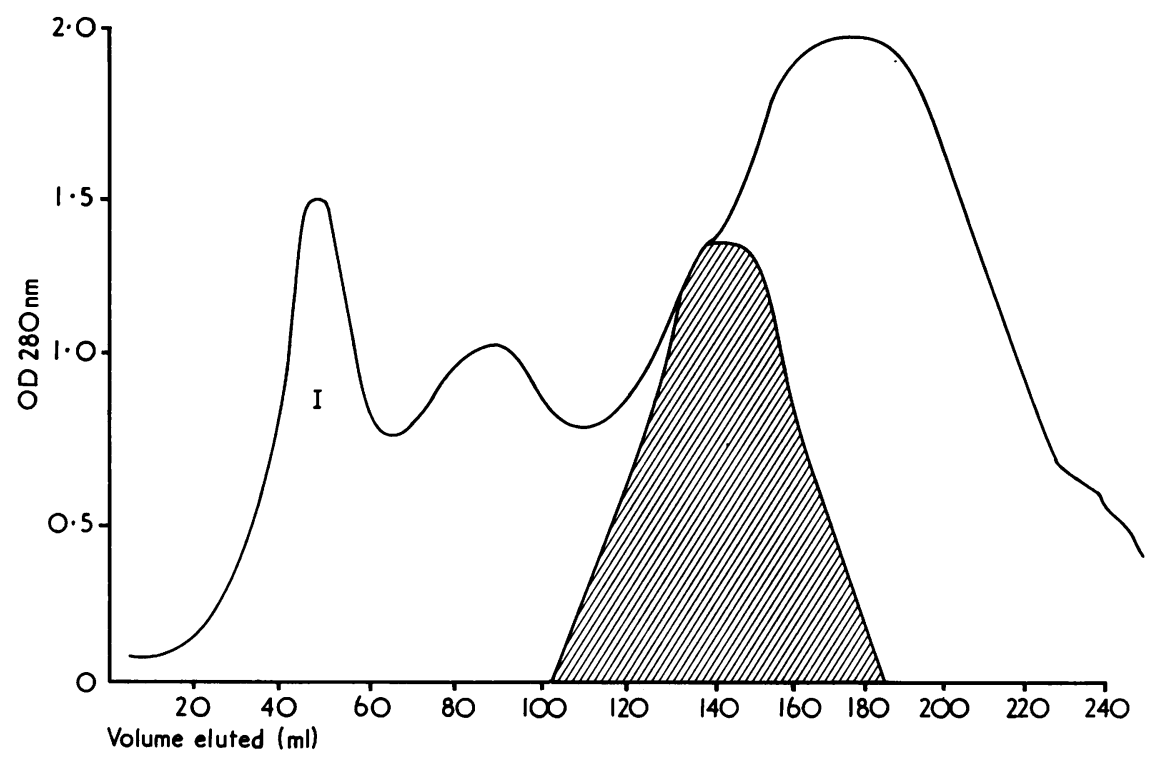

Figure Protein elution pattern of patient's plasma applied to a $5 \%$ agarose gel column

had no effect on increasing clot stability. The inhibitor appeared to be closely associated in time with other organ antibodies. Disappearance of all these factors within nine months of cessation of practolol therapy strongly implicates this drug in the causation of the patient's illness.

The question is thus raised whether all the abnormalities described can be related directly to the effect of practolol in a previously normal individual or whether this patient had a potential SLE diathesis which was revealed by treatment with practolol.

Inhibitors to clotting factors are not unusual in SLE per se. The commonest type is directed against the prothrombin complex (Margolius et al., 1961). Antibodies against factors VIII (Robboy et al., 1970), IX, and XI (Castro et al., 1972) accompanying this syndrome have also been described but not previously against factor XIII.

Factor XIII acts at a late stage in the coagulation process after activation by thrombin. Active factor XIII $\left(\mathrm{XIII}^{\mathrm{a}}\right)$ catalyses the transamidation reaction between $\gamma$-glutamyl and $\epsilon$-lysine residues of adjacent fibrin monomers. The product, ligated fibrin, is more resistant to mechanical and enzymatic degradation than is non-crosslinked fibrin (Lorand, 1970; Lorand and Gotoh, 1970).

There are several previous reports of factor XIII inhibitors (Lewis et al., 1967; Godal, 1970; Fiore et al., 1971; Lorand et al., 1972; McDevitt et al., 1972; Otis et al., 1974; Rosenberg et al., 1974).In somecases the exact point of inhibition of the enzyme has been delineated. Sites of action demonstrated have been (a) inhibition of the activation of factor XIII by thrombin (Lorand et al., 1972); (b) inhibition of the transpeptidation reaction where isopeptide bonds are formed between adjacent fibrin chains (Otis et al., 1974; Lorand et al., 1968); and (c) interference with cross-linking of fibrin by blocking of cross-linkage sites (Rosenberg et al., 1974). The inhibitor in our case appears to act at stage (b) (the enzyme reaction) because, as well as inhibiting fibrin cross-linking, the catalysis of incorporation of ${ }^{14} \mathrm{C}$ putrescine and monodansyl cadaverine into casein by preactivated factor XIII was also impaired.

Studies are under way to characterise further the inhibitor whose heat-liability suggests it is probably a protein and which has been shown to have a molecular weight similar to that of the major 7S component of bovine globulin. It is possible that the inhibitor is an immunoglobulin directed against factor XIII.

In several of the previous case reports treatment with isoniazid was implicated in the pathogenesis of an inhibitor to factor XIII (Fiore et al., 1971; Lorand et al., 1972; Otis et al., 1974; Lorand et al., 1968). No evidence for an SLE-like syndrome was produced in any of these reports, and various different pathogenic mechanisms have been suggested. These include modification of the factor XIII molecule by isoniazid with subsequent formation of an autoantibody (Lorand et al., 1972), modification of fibrin-fibrinogen by isoniazid with formation of an 
autoantibody against cross-linking sites (Rosenberg et al., 1974), and incorporation of isoniazid into plasma protein with the subsequent provision of a competitive amine donor for the transpeptidation step (Otis et al., 1974; Lorand et al., 1968). It is of interest that isoniazid is one of the therapeutic agents capable of causing drug-induced SLE. Our patient, however, had never received isoniazid.

The patient remains under close observation and is clinically well two-and-a-half years after his initial presentation.

We are most grateful to Dr P. L. Walton for performing the further studies on factor XIII and to $\mathrm{Mr}$ S. J. Jackson and Miss C. Luck for expert technical assistance.

\section{References}

Brown, P., Baddeley, H., Read, A. E., Davies, J. D., and McGarry, J. (1974). Sclerosing peritonitis, an unusual reaction to a beta-adrenergic-blocking drug (practolol). Lancet, $2.1477-1481$.

Castro, O., Farber, L. R., and Clyne, L. P. (1968). Circulating anticoagulants against factors IX and XI in systemic lupus erythematosus. Annals of Internal Medicine, 77, 543-548.

Fiore, P. A., Ellis, L. D., Dameshek, H. L., and Lewis, J. H. (1971). XIII inhibitor and antituberculous therapy (abstract). Clinical Research, 19, 418.

Godal, H. C. (1970). An inhibitor to fibrin stabilizing factor (FSF factor XIII). Scandinavian Journal of Haematology, 7, 43-48.

Lewis, J. H., Szeto, I. L. F., Ellis, L. D., and Bayer, W. L. (1967). An acquired inhibitor to coagulation factor 13. Johns Hopkins Medical Journal, 120, 401-407.

Lorand, L. (1970). Physiological crosslinking of fibrin. Thrombosis et Diathesis Haemorrhagica, Supplement, 39, 75-102.

Lorand, L. and Gotoh, T. (1970). Fibrinoligase. The fibrin stabilizing factor system. In Methods of Enzy- mology, Vol. 19, edited by G. Perlman and L. Lorand, p. 770. Academic Press, New York.

Lorand, L., Jacobsen, A., and Bruner-Lorand, J. (1968). A pathological inhibitor of fibrin cross-linking. Journal of Clinical Investigation, 47, 268-273.

Lorand, L., Maldonado, N., Fradera, J., Atencio, A. C., Robertson, B., and Urayama, T. (1972). Haemorrhagic syndrome of autoimmune origin with a specific inhibitor against fibrin stabilizing factor (factor XIII). British Journal of Haematology, 23, 17-27.

Lorand, L., Urayama, T., De Kiewiet, J. W. C., and Nossel, H. L. (1969). Diagnostic and genetic studies on fibrin-stabilizing factor with a new assay based on amine incorporation. Journal of Clinical Investigation, 48, 1054-1064.

McDevitt, N. B., McDonagh, J., Taylor, H. L., and Roberts, H. R. (1972). An acquired inhibitor to factor XIII. Archives of Internal Medicine, 130, 772-777.

Margolius, A., Jr., Jackson, D. P., and Ratnoff, O. D. (1961). Circulating anticoagulants: a study of 40 cases and a review of the literature. Medicine, 40, 145-202.

Nussbaum, M. and Morse, B. S. (1964). Plasma fibrin stabilizing factor activity in various diseases. Blood, 23, 669-678.

Otis, P. T., Feinstein, D. I., Rapaport, S. I., and Patch, M. J. (1974). An acquired inhibitor of fibrin stabilization associated with isoniazid therapy: clinical and biochemical observations. Blood, 44, 771-781.

Raftery, E. B. and Denman, A. M. (1973). Systemic lupus erythematosus syndrome induced by practolol. British Medical Journal, 2, 452-455.

Robboy, S. J., Lewis, E. J., Schur, P. H., and Colman, R. W. (1970). Circulating anticoagulants to factor VIII. American Journal of Medicine, 49, 742-752.

Rosenberg, R. D., Colman, R. W., and Lorand, L. (1974). A new haemorrhagic disorder with defective fibrin stabilization and cryofibrinogenaemia. British Journal of Haematology, 26, 269-284.

Walton, P. L. and Luck, C. M. (1976). Unpublished observations.

Wright, P. (1975). Untoward effects associated with practolol administration: oculomucocutaneous syndrome. British Medical Journal, 1, 595-598. 